We have observed that when felts of the same mould are placed on Hida's salt solution to which ethyl acetoacetate ( 1 per cent $w / v$ ) has been added, this solution after about eight days at $30^{\circ}$ contains pyruvic acid, dimethylpyruvic acid, $\alpha$-ketoglutaric acid and again the same unidentified keto-acid encountered in the other experiments. In all instances the presence of these products was established chromatographically and was verified in repeated experiments. Work with the object of isolating the ditferent products in the form of crystalline derivatives is now in progress in these laboratories.

The strain of $A$. niger employed in these experiments is one that gives only small yields of citric acid from glucose (10-15 per cent of the glucose utilized); and, in view of this, our results would seem to indicate that citrate accumulates in sugar cultures of those strains of $A$. niger in which the enzyme system metabolizing citric acid is either deficient or weak, and that in other strains of this mould any citric acid produced is afterwards transformed, in part at least, by way of the tricarboxylic acid cycle.

Our detection of dimethylpyruvic acid and of $\alpha$-ketoglutaric acid in the mixture of products arising from both carbohydrate and ethyl acetoacetate may be an indication that the mechanisms by which the mould converts glucose to citric acid, and to the 4-carbon dicarboxylic acids common to the SzentGyörgyi systems in equilibrium and the Krebs cycle, are linked closely to those which give rise to certain acidic products and derivatives of the same which are all built on the isoprene skeleton.

During the progress of these studies, we learned from Dr. D. J. D. Hockenhull, a former colleague at Manchester, that work on parallel lines was being undertaken by Glaxo Laboratories, Ltd. This led to our consultation and an exchange of views on matters of mutual interest, and it is a pleasure to acknowledge this friendly collaboration. We desire to thank Prof. H. A. Krebs for the gift of a specimen of the 2:4 dinitrophenylhydrazone of $\alpha$-ketoglutaric acid which we have used for purposes of comparison.

\section{T. K. WALKER}

A. N. Hari

J. W. HOPTON

College of Technology,

Manchester 1. Sept. 19.

${ }^{1}$ Ramachandran, K., and Walker, T. K., Arch. Biochem. and Biophys. 31, (2), 224 (1951).

${ }^{2}$ Hida, T. J. Shanghai Sci. Inst., Sect. iv (1), 201 (1935).

${ }^{3}$ Cavallini, D., Frontali, N., and Toschi, G., Nature, 163, 568 (1949).

" Krebs, H. A., and Eggleston, L. V., Biochem. J., 34, 1383 (1940).

${ }^{5}$ Lockwood, I. B., and Stodola, F. H., J. Biol. Chem., 164, 81 (1946)

${ }^{6}$ Uemura, T., J. Agric. Chem. Soc. Japan, 15, 353 (1939), from Chem. Abs., 33, $8872(1939)$.

\section{Production of Ketoglutarate by Penicillium chrysogenum}

Krebs and Fggleston ${ }^{1}$ have isolated ketoglutaric acid (I) during a study of arsenite-inhibited pyruvate utilization by pigeon's breast muscle. Lockwood and Stodola ${ }^{2}$ have isolated substantial yields of the same compound from a Pseudomonas fluorescens fermenta. tion of glucose. From moulds its isolation has been reported only by Uemura ${ }^{3}$, who obtained it on deamination of glutamic acid by Aspergillus oryzce.

When washed, starved mycelial suspensions from $P$. chrysogenum $Q 176$ var. brevisterigm. $a^{4}$, originally grown in submerged culture, had been shaken aerobically with lactate in presence of arsenite, substantial amounts of keto-acids could be isolated; we determined their nature after filter-paper chromatography (Cavallini et al. ${ }^{5}$ ), using water-saturated sec. butanol. Substantial yields, consisting almost exclusively of ketoglutaric acid, were frequently obtained.

In presence of $0.01 \mathrm{M}$ sodium arsenite at $p \mathrm{H} .7 \cdot 3$, we obtained $400 \mathrm{mgm}$. of the crude $2: 4$-dinitrophenylhydrazone of ketoglutarate from $2 \cdot 8 \mathrm{gm}$. potassium lactate. After crystallization from ethyl acetate, light petroleum (boiling point $40-60^{\circ}$ ) and ethanol, it melted at $217-218^{\circ}$ (authentic phenylhydrazone, melting point $219^{\circ}$, and a mixture, 218$219^{\circ}$ : $\mathrm{C}, 40.87 ; \mathrm{H}, 3.23 ; \mathrm{N}, 16.90$ per cent; authentic phenylhydrazone required $\mathrm{C}, 40.50 ; \mathrm{H}$, $3 \cdot 07 ; \mathrm{N}, 17 \cdot 18$ per cent).

It was later found that, at $p \mathbf{H} 5 \cdot 0$ as opposed to the original $p \mathrm{H} 7 \cdot 3$, inhibitor was not necessary for the production of keto-acids.

From $1.0 \mathrm{gm}$. of potassium lactate we obtained $0.80 \mathrm{gm}$. of the phenylhydrazone contaminated with material having an $R_{F}$ between those of the derivatives of pyruvate and dimethyl pyruvate. By chromatography on alumina a large fraction of the nearly pure phenylhydrazone, weighing about $550 \mathrm{mgm}$., was isolated; it was recrystallized from ethyl acetate - light petroleum to give a product that melted at 218-219 $9^{\circ}$ and did not depress the melting point of authentic $2: 4$-dinitrophenylhydrazone of ketoglutarate.

A fuller account of this work is being submitted for publication elsewhere. We are happy to acknow. ledge a friendly interchange of views and collaboration with Dr. T. K. Walker and his colleagues at Manchester, who have been working on parallel lines?. D. J. D. HockenHuLr

G. D. WILKIN F. G. WINDER

Glaxo Laboratories, Ltd., Sefton Park, Stoke Poges, Bucks. Sept. 19.

${ }^{1} \mathrm{Krebs}$, H. A., and Eggleston, L. V., Biochem. J., 34, 1383 (1940).

${ }^{2}$ Lockwood, L. B., and Stodola, T. H., J. Biol. Chem., 164, 81 (1946). 3 Uemura, T., J. Agric. Chem. Soc. Japan, 15, 353 (1939), from Chem. Abs., $13 ., 3872(1939)$.

4 Foster, J. W. U.S.P. 2,458,495 (Jan. 11, 1949).

${ }^{5}$ Cavallini, D., Frontali, N., and Toschi, G., Nature, 163, 568 (1949).

- Datta, S. P., Harris, H., and Rees, K. R., Biochem. J., 46, xxxvi (Proc. Biochem. Soc.) (1950).

'Walker, T. K., Hall, A. N., and Hopton, J. W. (see preceding communication).

\section{Inositol, a Major Constituent of the Seminal Vesicle Secretion of the Boar}

IN the course of the recent isolation of ergothioneine from boar's vesicular secretion ${ }^{1}$, an alcohol-precipitable fraction was separated which did not contain nitrogen or sulphur; upon further purification of this fraction, crystalline material was obtained which tasted distinctly sweet, was optically inactive and non-reducing, and which gave a strongly positive Scherer reaction ${ }^{2,3}$ characteristic of inositol. After recrystallization, first from ethanol and next from water, $18 \mathrm{gm}$. of pure meso-inositol was obtained from 1 litre of the vesicular secretion. The substance had a melting point of $225^{\circ} \mathrm{C}$., and was found to contain 40.28 per cent $C$ and 6.79 per cent $H$ as against $40 \cdot 11$ per cent $C$ and 6.66 per cent $H$ expected theoretically; on oxidation with periodic acid ${ }^{4}$ it showed a titration curve identical with that of pure meso-inositol. The concentration of inositol in the boar's seminal vesicle secretion exceeds considerably the amounts hitherto recorded for material 